\title{
SALT INDUCED CHANGES IN DRY MATTER ACCUMULATION AND YIELD OF MUSTARD (Brassica juncea)
}

\author{
M. M. Zaman'1 , M. A. Mannan ${ }^{2}$ and S. C. Samanta ${ }^{3}$ \\ ${ }^{1}$ Regional Training Coordinator, USAID Agriculture Extension Project, Jessore \\ ${ }^{2}$ Department of Agronomy, Bangabandhu Sheikh Mujibur Rahman Agricultural University, Gazipur-1706 \\ ${ }^{3}$ Department of Agronomy, Patuakhali Science and Technology University, Patuakhali-8602 \\ Corresponding author: mannanbsmrau@yahoo.com
}

Keywords: Mustard, salinity, irrigation water, dry matter, seed yield

\begin{abstract}
The experiment was laid down to identify mustard [Brassica juncea (L.) Czern \& Coss] genotype tolerant to soil salinity in relation to shoot and total dry matter (root+shoot) plant $^{-1}$, number of siliqua plant ${ }^{-1}$, number of seed siliqua ${ }^{-1}, 1000$-seed weight and seed yield plant ${ }^{-1}$. Four genotypes (BD 9080, BARI Sarisha16, BD 9109 and BD 9107) were evaluated at three levels of $\mathrm{NaCl}$ salinity, viz. 0 (normal), 50 and $100 \mathrm{mM}$. All of the mustard genotypes showed decreasing trend with respect to all of the above mentioned crop parameters with salinity over normal water and thee decreasing rate of the parameters was higher with the increasing salinity levels. Among the genotypes, BD 9080 showed the best performance with respect to above mentioned characters at all levels of salinity, while BD 9107 performed the poorest. Thus, genotype BD 9080 proved to be more tolerant to salinity than other genotypes.
\end{abstract}

\section{Introduction}

Mustard (Brassica spp.) is one of the most important oilseed crops throughout the world after soybean and groundnut (FAO, 2004). Among the oilseed crops grown in Bangladesh mustard holds the first position in terms of both total cultivation area and production and that was 2,52,227 ha and 2,46,000 tons, respectively (BBS, 2012). In Bangladesh about 1.5 million ha of coastal land is affected by different degrees of salinity. Most of the southern districts of the country are under saline zones which cover an area of $25-30 \%$ of the total cultivable land (SRDI, 2012). Salinity reduces growth and yield of non-halophyte by decreasing the availability of water to the roots due to the osmotic effect of external salt and by creating toxic effects of excessive salt accumulation within the plant. Salinity occurs through natural or human induced activities that result in the accumulation of soluble salt in soil and the problem of soil salinity expected to boost in future with the progress of desertification process and greenhouse effect. Mustard (Brassica juncea) is a glycophytes, which often experiences saline stress as it is grown extensively in the arid and semi-arid regions of the world (Singh et al., 2001). Hence, it becomes necessary to examine the underlying processes involved in salt tolerance in mustard plants. While screening some cultivars of B. juncea, Hayat et al. (2011) categorized cv. Varuna as salt tolerant and cv. Rohini as salt sensitive and attributed this differential salt tolerance to salt-induced changes in fresh and dry biomass. Though soil salinity is the most dominant factors limiting crop production in the saline areas of Bangladesh during dry season, salt tolerant mustard crop can bring substantial changes in the agricultural practices in that problem soils. Taking this into consideration, the present study was undertaken to examine the salt-induced modulation in the dry matter accumulation and yield in salt-tolerant and salt sensitive mustard genotypes. 
Zaman et al.

\section{Materials and Methods}

An experiment was conducted in earthen pots of $24 \mathrm{~cm}$ in diameter and $30 \mathrm{~cm}$ in height in net house under semi controlled environment (inside plastic house) and natural light in the Department of Agronomy, Patuakhali Science and Technology University, Patuakhali, Bangladesh during Rabi 2011-12. Each pot was filled with mixture of $12 \mathrm{~kg}$ air-dried soil, compost (25\% of the soil volume) and $0.35-0.38-0.22 \mathrm{~g}$ of urea, TSP and MOP. Ten uniform bold seeds of four mustard genotypes viz.BD 9080, BARI Sarisha16, BD 9109 and BD 9107 were sown at first week of October 2011. The soil used in experiment was clay loam in texture having $\mathrm{pH}$ 6.9, ECe0.33 dS/m, ESP 8.2 per cent, CEC $16.69 \mathrm{cmol}_{\mathrm{c}} \mathrm{kg}^{-1} \mathrm{dry}$ soil and organic carbon 0.55 per cent. After seedling establishment, five uniform and healthy plants were allowed to grow. Intercultural operations, weeding and pest control measures were taken properly when necessary. At autotrophic stage, sufficient quantities of salt solution were applied in treated pot. Salt solution was prepared artificially by dissolving calculated amount of commercially available $\mathrm{NaCl}$ with tap water to make 50 and $100 \mathrm{mM} \mathrm{NaCl}$ solution which electrical conductivity (EC) were equivalent to 5 and $10 \mathrm{dS} / \mathrm{m}$, respectively. To avoid salt stress shock, the salt solution was applied with an increment of $25 \mathrm{mM}$ in every alternate day till respective concentrations were attained. Plants in control group were irrigated with tap water (normal). The salt solutions were applied till harvest. The experiment carried out in Completely Randomized Design with four replications. The observations on shoot and total dry matter per plant, number of siliqua per plant, number of seeds per siliqua, 1000-seed weight and seed yield per plant were recorded. The data recorded for different parameters were statistically analyzed using MSTAT-C computer program and mean differences were adjusted by LSD technique (Gomez and Gomez, 1984).

\section{Results and Discussion}

\section{Shoot dry matter per plant}

Shoot dry weight of all mustard genotypes was affected by both salinity levels significantly. Reduction in shoot dry weight due to salinity was lower in genotype BD 9080, whereas that was higher in BD 9107. The shoot dry weight was reduced by 37\% in genotype BD 9080 and by about 59\% in BD 9107 at $100 \mathrm{mM} \mathrm{NaCl}$ salinity (Fig. 1). Shoot dry matter reduction was more than $50 \%$ in other genotypes under higher salinity level. Shoot dry matter was also significantly affected at $50 \mathrm{mM} \mathrm{NaCl}$ salinity level. Compared to other genotypes studied, genotype BD 9080 was less affected by $50 \mathrm{mM} \mathrm{NaCl}$ salinity stress. In respect of shoot dry matter production under saline environment, genotype BD 9080 showed higher salt tolerance than the other genotypes. Reduction in shoot dry weight due to salinity as compared to control was reported earlier by Ghuge et al. (2011) in two Brassica juncea cultivars and Raziuddin et al. (2011) Brassica napus (cultivar Abasin) and Brassica juncea (cultivar NIFA-Raya). It was reported that salt stress caused low photosynthesis $(\mathrm{Pn})$ which was associated with a low demand for photosynthate in the sink (Sultana et al., 1999). The less reduction in photosynthesis of tolerant genotypes at high salt concentration than susceptible group might have contributed to maintain better growth through shoot dry matter production in the genotype BD 9080 than the BD 9107. 


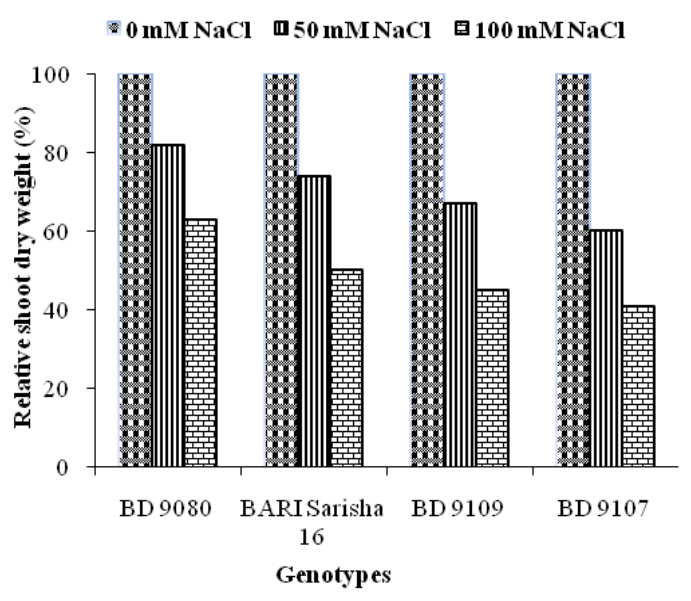

Fig. 1. Relative shoot dry weight of four mustard genotypes as affected by salinity

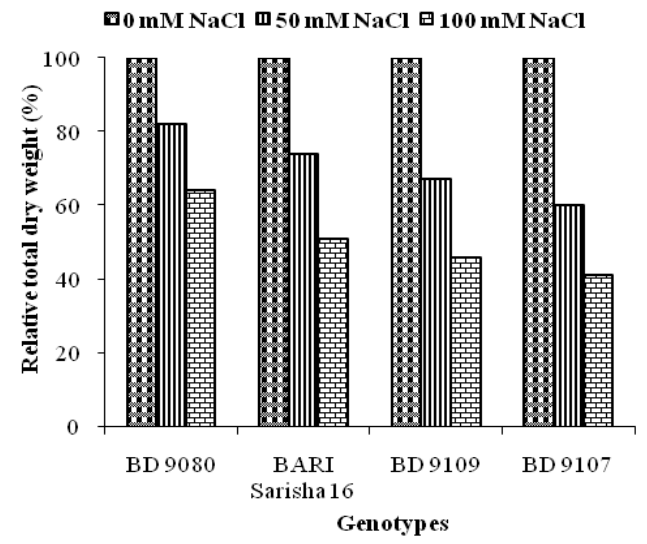

Fig. 2. Relative total dry weight of four mustard genotypes as affected by salinity

\section{Total dry matter per plant}

Both $50 \mathrm{mM}$ and $100 \mathrm{mM} \mathrm{NaCl}$ salinity affected significantly the total dry matter production in all the mustard genotypes studied. Total dry matter reduction due to salinity was lower at 50 $\mathrm{mM}$ salinity level than that at $100 \mathrm{mM} \mathrm{NaCl}$ level. Salinity induced differences in total dry matter production among the genotypes were caused by the differences in the reduction of root, leaf, and stem dry matter over their control (Data not present). The minimum reduction in total dry matter was noticed in genotype BD 9080 (36\%), whereas the maximum (59\%) was in genotype BD 9107 (Fig. 2). The dry matter reduction in BARI Sarisha16 and Genotype BD 9109 was in between this minimum and maximum range. The total dry matter in BD 9080 was less affected even at high salinity level, which could be attributed to more efficient production of leaf, stem and root dry matter. Thus, dry weight per plant was adversely affected by increasing levels of salinity. Reduction in total dry matter accumulation under saline condition was also reported by Neelam et al. (2010) and Shamsul et al. (2011) in Indian mustard (Brassica juncea) and Memon et al. (2010) in Brassica campestris L.

\section{Number of siliqua plant ${ }^{-1}$}

Number of siliquae reduced significantly with each increase in salinity level. The reduction was higher at $100 \mathrm{mM} \mathrm{NaCl}$ salinity compared to that at $50 \mathrm{mM} \mathrm{NaCl}$. The reduction in siliqua per plant at $50 \mathrm{mM} \mathrm{NaCl}$ ranged from 5\% to $35 \%$. However, at $100 \mathrm{mM} \mathrm{NaCl}$ genotype BD 9107 produced only $42 \%$ siliqua of the control. The production of siliqua per plant at $100 \mathrm{mM} \mathrm{NaCl}$ reduced to a great extent and ranged from $12 \%$ (in genotype $\mathrm{BD} 9080$ ) to $58 \%$ (in genotype BD 9107) (Table 1). Negative effect of salinity on number of siliqua per plant of Indian mustard [Brassica juncea (L.) Czern \& Coss] was also observed by Kripa et al. (2011).

\section{Number of seeds siliqua ${ }^{-1}$}

Salinity also reduced the average number of seeds per siliqua significantly in all the mustard genotypes studied (Table 1). The number of seeds per siliqua was affected a little by $50 \mathrm{mM}$ $\mathrm{NaCl}$ salinity in most of the genotypes, except genotype BD 9107 . Under $100 \mathrm{mM} \mathrm{NaCl}$ salt stress, the highest relative seed number per siliqua was produced by the genotype BD 9080 (74\%), followed by BARI Sarisha 16 (63\%) and BD 9109 (45\%) and the lowest by genotype 
Zaman et al.

BD 9107 (33\%). These results corroborate to the findings of Omae et al. (2005) and Ahmad (2010).

\section{Thousand seed weight (gm)}

1000 -seed weight showed significant reduction with increase in salinity level in all the mustard genotypes studied. At $50 \mathrm{mM} \mathrm{NaCl}$ salinity level, 1000-seed weight ranged from $2.12 \mathrm{~g}$ to $3.02 \mathrm{~g}$, whereas at $100 \mathrm{mM} \mathrm{NaCl}$ that was from $1.77 \mathrm{~g}$ to $2.87 \mathrm{~g}$ (Table 2). Relative grain weight was the highest in genotype BD 9080 (86 \%), followed by BARI Sarisha16 (76 \%) and BD 9109 (72\%), and it was the lowest in genotype BD 9107 (51\%) at $100 \mathrm{mM} \mathrm{NaCl}$. A remarkable reduction in the size of seeds was observed at $100 \mathrm{mM} \mathrm{NaCl}$ in all the genotypes. It might be attributed to disturbed absorption of moisture and nutrients, limited formation of photosynthates and their lesser translocation towards seeds resulting reduction in seed weight.

Table 1. Number of siliqua per plant and number of seeds per siliqua of four mustard genotypes as affected by $\mathrm{NaCl}$ salinity

\begin{tabular}{l|c|c|c|c|c|c}
\hline \multirow{2}{*}{ Genotypes } & \multicolumn{3}{c|}{ Number of siliqua plant ${ }^{-1}$} & \multicolumn{3}{c}{ Number of seeds siliqua-1 } \\
\cline { 2 - 7 } & 0 & 50 & 100 & 0 & 50 & 100 \\
\cline { 2 - 7 } & 82.25 & 78.50 & 72.00 & 16.25 & 15.00 & 12.00 \\
BD 9080 & \multicolumn{3}{c}{$\mathrm{NaCl}(\mathrm{mM})$} & $(95)$ & $(74)$ \\
BARI Sarisha16 & 185.50 & 167.25 & 151.50 & 10.00 & 8.00 & 6.25 \\
& & $(90)$ & $(82)$ & & $(80)$ & $(63)$ \\
BD 9109 & 71.25 & 62.75 & 50.75 & 29.75 & 18.00 & 13.50 \\
& & $(88)$ & $(71)$ & & $(61)$ & $(45)$ \\
BD 9107 & 82.50 & 54.25 & 34.75 & 21.25 & 13.25 & 7.00 \\
& & $(65)$ & $(42)$ & & $(45)$ & $(33)$ \\
\hline LSD (0.01) & 6.84 & & 4.31 & 15.61 \\
CV (\%) & \multicolumn{3}{c}{3.88} \\
\hline
\end{tabular}

Values presented in parentheses indicate per cent values to the control.

In genotype BD 9080, relative seed weight was higher with compared to other genotypes which indicated that this genotype was more capable to partition more dry matter into the seeds than that of other genotypes, especially at higher level of salinity.

\section{Seed yield}

An inverse relationship was found between salinity levels and seed yield in mustard. Seed yield was reduced by salinity in all the mustard genotypes studied and the decreasing rate was higher with the increasing level of salinity. Seed yield of different genotypes ranged from 4.43 to 6.00 g plant ${ }^{-1}$ under normal condition and that from 2.96 to 5.61 and 2.49 to $5.24 \mathrm{~g} \mathrm{plant}^{-1}$ under $50 \mathrm{mM}$ and $100 \mathrm{mM} \mathrm{NaCl}$ saline conditions, respectively (Table 2). The highest relative seed yield plant ${ }^{-1}$ was found in genotype $\mathrm{BD} 9080$ at both the salinity levels and the lowest was in genotype BD 9107. Most of the yield contributing traits is less affected under $100 \mathrm{mM} \mathrm{NaCl}$ stress in genotype $\mathrm{BD} 9080$. So yield difference of $50 \mathrm{mM}$ and $100 \mathrm{mM} \mathrm{NaCl}$ is very near of this genotype. The highest relative number of siliqua plant ${ }^{-1}$ and individual seed weight in genotype BD 9080 mostly contributed to the highest relative seed yield of this genotype. 
Salt Induced in DMA and Yield of Mustard

Table 2. 1000-seed weight and seed yield plant ${ }^{-1}$ of four mustard genotypes as affected by $\mathrm{NaCl}$ salinity

\begin{tabular}{|c|c|c|c|c|c|c|}
\hline \multirow[t]{3}{*}{ Genotypes } & \multicolumn{3}{|c|}{ 1000-seed weight (g) } & \multicolumn{3}{|c|}{ Seed yield (g) plant ${ }^{-1}$} \\
\hline & \multicolumn{3}{|c|}{$\mathrm{NaCl}(\mathrm{mM})$} & \multicolumn{3}{|c|}{$\mathrm{NaCl}(\mathrm{mM})$} \\
\hline & 0 & 50 & 100 & 0 & 50 & 100 \\
\hline \multirow[t]{2}{*}{ BD 9080} & 3.33 & 3.02 & 2.87 & 6.00 & 5.61 & 5.24 \\
\hline & & $(91)$ & (86) & & (93) & (87) \\
\hline \multirow[t]{2}{*}{ BARI Sarisha16 } & 3.75 & 3.0 & 2.85 & 4.43 & 3.71 & 3.22 \\
\hline & & $(80)$ & (76) & & (83) & (72) \\
\hline \multirow[t]{2}{*}{ BD 9109} & 3.65 & 2.70 & 2.63 & 5.38 & 4.22 & 3.26 \\
\hline & & $(74)$ & (72) & & (78) & $(60)$ \\
\hline \multirow[t]{2}{*}{ BD 9107} & 3.45 & 2.12 & 1.77 & 5.66 & 2.96 & 2.49 \\
\hline & & $(61)$ & $(51)$ & & $(52)$ & (43) \\
\hline LSD $(0.01)$ & \multicolumn{3}{|c|}{0.76} & \multicolumn{3}{|c|}{0.37} \\
\hline CV (\%) & \multicolumn{3}{|c|}{12.97} & \multicolumn{3}{|c|}{4.26} \\
\hline
\end{tabular}

Values presented in parentheses indicate per cent values to the control.

This finding supported by Kripa et al. (2011). The poor seed yield under saline environment was attributed to salt induced shrinkage and even complete damage of chloroplast, decrease in photosynthates in the phloem and water deficiency in the growing region (Flowers et al, 1991). According to Ashraf et al. (1999) the reduction in seed yield may also be due to decreasing assimilates production associated with decreased plant size and yield.

The correlation matrix between the yield attributes of mustard subjected to salinity (Table 3) showed that seed yield plant ${ }^{-1}$ was strongly associated with the shoot mass $\operatorname{plant}^{-1}\left(r=0.829^{* *}\right)$, number of siliqua plant ${ }^{-1}\left(r=0.904^{* *}\right)$ and number of seed siliqua ${ }^{-1}\left(r=0.981^{* *}\right)$. There were a weak relation between yield and 1000-seed weight (0.538*). Weight of 1000-seed ( $\left.r=0.344^{*}\right)$, number of siliqua plant ${ }^{-1}\left(r=0.532^{*}\right)$ and number of seed siliqua ${ }^{-1}\left(r=0.349^{*}\right)$ were positively related to shoot mass plant ${ }^{-1}$. Correlation coefficient analysis showed that among those components number of siliqua plant ${ }^{-1}$ had the maximum direct contribution to yield and number of seed siliqua ${ }^{-1}$ and individual seed weight were the dominant contributors to seed yield.

Table 3. Correlation coefficient $(r)$ among the shoot mass and yield attributes of mustard subjected to salinity

\begin{tabular}{l|c|c|c|c|c}
\hline Characters & $\begin{array}{c}\text { Shoot } \\
\text { mass } \\
\text { plant }^{-1}\end{array}$ & $\begin{array}{c}\text { Number of } \\
\text { siliqua } \\
\text { plant }^{-1}\end{array}$ & $\begin{array}{c}\text { Number of } \\
\text { seeds } \\
\text { siliqua }\end{array}$ & $\begin{array}{c}1000- \\
\text { seed } \\
\text { weight } \\
\text { (gm) }\end{array}$ & $\begin{array}{c}\text { Yield plant } \\
1\end{array}$ \\
\hline Shoot mass per plant & - & $0.532^{*}$ & $0.349^{*}$ & $0.344^{*}$ & $0.829^{* *}$ \\
Number of siliqua per plant & - & - & $0.669^{* *}$ & $0.524^{\mathrm{ns}}$ & $0.904^{* *}$ \\
Number of seeds per siliqua & - & - & - & $0.304 \mathrm{~ns}$ & $0.981^{* *}$ \\
1000-seed weight & - & - & - & - & $0.538^{*}$
\end{tabular}

** Correlation is significant at the 0.01 level (2-tailed).

* Correlation is significant at the 0.05 level (2-tailed).

ns - non significant 
Zaman et al.

\section{References}

Ahmad, B. 2010. Effects of salinity on yield and component characters in canola (Brassica napus L.) cultivars. Not. Sci. Biol. 2 (1): 81-83.

Ashraf, M. Y., R. A. Waheed, A. Bhatti, S. A. Baig and Z. Aslam. 1999. Salt tolerance potential in different Brassica species: Growth studies. P. 119-125. In: Harndy, A., H. Lieth, M. Todorovic and M. Moscheuko. (eds.) Halophyte Use in Different Climates II.Backhuy Pubs. Leiden, The Netherlands.

BBS (Bangladesh Bureau of Statistics) 2012. Agriculture Wing, Statistical Pocket Book of Bangladesh, Planning Division, Ministry of Planning, Government of Bangladesh.

FAO (Food and Agricultural Organization of the United Nations) 2004. TerraSTAT database. At: $<\mathrm{http}: / /$ www.fao.org/ag/agl/agll/terrastat/>.

Flowers, T. J., M. A. Hajibagheri and A. R. Yeo. 1991. Ion accumulation in the cell walls of rice plants growing under saline conditions: evidence for the Oertli hypothesis. Plant Cell Environ. 14:319-325.

Gomez, A. A. and A. A. Gomez. 1984. Statistical procedure of Agricultural Research. John Wiley and Sons. New York. pp. 20-215.

Hayat, S., B. A. Mir, A. S. Wani, S. A. Hasan, M. Irfan and A. Ahmad. 2011. Screening of salttolerant genotypes of Brassica juncea based on photosynthetic attributes. J. Plant Interact. 6: 53-60.

Kripa, S., S. K. S. Parihar, K. Kuldeep,D. Kant and K. Arun. 2011. Relative salt tolerance of Indian mustard (Brassica juncea) genotypes in relation to germination, growth and seed yield. J. Oilseed Brassica. 2(2): 76-82.

Neelam, S., G. Dipti and K. Navjyot. 2010. Effect of induced salinity stress on growth and yield of Indian mustard (Brassica juncea). Environ. Ecol. 28 (2): 967-968.

Omae, H., A. Kumar, Y. Egawa, K. Kshiwaba and M. Shono.2005. Genotypic differences in plant water status and relationship with reproductive responses in snap bean (Phaseolus vulgaris L.) during water stress. Jpn. J. Trop. Agric. 49: 1-7.

Raziuddin, F., H. Ghulam, M. Akmal, S. S. Shah, M. Fida,. M. Shafi, B. Jehan and W. Zhou. 2011. Effects of cadmium and salinity on growth and photosynthesis arameters of Brassica species. Pak. J. Bot. 43 (1): 333-340.

Shamsul, H., B. A. Mir, A. S. Wani, S. A. Hasan, I. Mohd, and A. Aqil. 2011. Screening of salttolerant genotypes of Brassica juncea based on photosynthetic attributes J. Plant Interactions. 6 (1): 53-60.

Singh, H., B. P. Singh and H. Prasad. 2001. Weed management in Brassica species. Indian J. Agron. 46: 533-537.

SRDI. 2012. Saline soils of Bangladesh. Soil Resources and Development Institute. Ministry of Agriculture, Farmgate, Dhaka-1215.

Sultana, N. T., T. Ikeda and R. Itoh, 1999. Effect of $\mathrm{NaCl}$ salinity on photosynthesis and dry matter accumulation in developing rice grains. Environ. and Experiment. Bot. 42: 211-220. 